\title{
Vedat Türkali'nin Güven Adlı Romanı'nda Şahıs Kadrosu Perspektifinden II. Dünya Savaşı'nın Topluma Etkileri
}

\author{
YASEMİN KOÇ*
}

Öz

Romanlar ele aldıkları dönemin tanıklığını yapan edebî metinlerdir. Bu tanıklık, roman kişileri, olay örgüsü ya da tematik doku aracılığıyla olabileceği gibi eserin dil ve üslup özellikleri açısından da gerçekleşebilir. Gerçekçi yaklaşıma sahip yazarlar, yaşanan gerçekliğe mümkün olduğunca sadık kalınması gerektiği inancıyla, romanın çağının tanıklı̆̆ını yapmasına daha fazla özen gösterirler.

Türk romanında bireysel gerçekçiliğin ve toplumsal gerçekçi çizginin önemli isimlerinden olan Vedat Türkali de romanlarının konu edilen tarihsel süreci yansıtmasına özen göstermiştir. Yazar, özellikle roman kişilerinden yola çıkarak, onların bireysel gerçekliğini derinlemesine incelerken, bir yandan da onları toplumsal panoramanın parçaları olarak sunar. Kişiler aracılığıyla çizilen bu panorama, belli tarihi süreçleri gerçekçi ya da farklı açılardan görebilmek açısından önemli bir katkı sağlar.

Vedat Türkali, Güven romanında II. Dünya Savaşı'nın yarattığı sıkıntılı günleri ve ekonomik darboğazı şahıs kadrosu vasıtasıyla gerçekçi bir şekilde çizer. Bu çalışmada yaşanan bu sancılı sürecin şahıs kadrosuna yansıyış biçimi, kişilerin değerlendirmeleri, tepkileri üzerinden anlamlandırılmaya çalışılacak.

Anahtar sözcükler: Roman, şahıslar, savaş, toplum, gerçekçilik.

THE EFFECTS OF WORLD WAR II ON THE COMMUNITY FROM THE PERSPECTIVE OF NARRATIVE PERSON IN VEDAT TÜRKALI'S NOVEL GÜVEN

\section{Abstract}

Novels are literary texts that testify to the period in which they handle. This testimony may occur through novel persons, plot or thematic texture, as well as in terms of the work's language and style features. Realistic writers believe that novels should testimony to the their ages. Hence, they try to remain faithful to the reality as far as possible.

\footnotetext{
*Adnan Menderes Üniversitesi, Sosyal Bilimler Enstitüsü, Yeni Türk Edebiyatı Doktora programı, yasminkoc07@gmail.com, orcid.org/0000-0001-5882-7623 
Vedat Türkali, one of the important names of individual realism and social realistic line in Turkish novel, also pays attention to reflect the historical processes in his novels. By starting from the novel persons, on the one hand, author examines their individual reality profoundly and on the other hand, he also presents them as parts of the social panorama. This panorama drawn through these persons makes a significant contribution to be able to seeing certain historical processes from realistic or different point of views.

In Güven, Vedat Türkali realistically portrays the troubled days of World War II and the economical difficulties through the narrative persons. In this study, the reflection style of this problematic process on the narrative persons will be evaluated through their considerations and reactions.

Keywords: Novel, characters, war, community, realism.

\section{GİRİ̧}

939-45 yılları II. Dünya Savaşı'nın tüm dünyayı etkisi altına aldığı yıllardır. “Milli şef dönemi” olarak da adlandırılan bu yıllarda İsmet İnönü, hem _ cumhurbaşkanı hem de CHP genel başkanlığı görevini yürütmektedir. İnönü, Celal Bayar'ı başbakanlıkta tutmanın yanı sıra genel başkan vekilliğine de atayarak kendisine yakın tutar.

1939-45 yılları Türkiye Cumhuriyeti'nin dış politikasını şekillendiren önemli bir döneme tanıklık eder. Türk hükümeti, 1939'da İngiltere ve Fransa ile karşılıklı yardım, 1941'de Almanlarla dostluk ve saldırmazlık antlaşması imzalar. İngiltere ve Amerika Türkiye'yi savaşa dâhil etmek istemektedir. Bu süreçte İsmet İnönü ince bir siyaset izleyerek savaşa girmez. Türkiye, Almanların Sovyet Rusya'ya saldırmasının ardından tarafsızlığını ilan eder. Savaşın sonuna kadar bu tutumunu sürdürmeye devam eder. Rus ordusu 1944'te Berlin'e ilerler. İşgal altındaki ülkeler de silahlı direnişe geçer. Ruslar birçok cephede Almanlara karşı saldırıya geçerek onları püskürtür. Hitler'in isteği Stalingrad'ı düşürmektir. Ancak bu isteğini gerçekleştiremez. Almanya'nın işgal edilmesi üzerine Adolf Hitler, 30 Nisan 1945 tarihinde intihar eder. Amerika Birleşik Devletleri, Japonya'nın teslim olmasını sağlamak amacıyla 1945 yılında Hiroşima'ya, kısa bir süre sonra da Nagasaki'ye atom bombası atar. Bu olay üzerine Japonya, kayıtsız şartsız teslim olmayı kabul eder.

Türkiye, katılmadığı halde bu savaştan oldukça etkilenir. Var olan dünya savaşı orduya ayrılan bütçenin arttırılmasına sebep olur. Oluşan bütçe açığını kapatmak için geçici çözümler aranır.

İkinci Dünya Savaşı'nda alınan zorunlu ekonomik tedbirler ülkede sermayenin belli ellerde toplanmasına neden olur. Ülkede görülmeye başlayan karaborsa ve vurgun hâli kent 
burjuvazisinin zenginleşmesini sağlar. Kırsal alanlarda ise toprak sahipleri ürünlerini yüksek fiyatlarla satarak büyük kârlar elde ederler.

Milli Koruma Kanunu, Varlık Vergisi, Toprak Mahsulleri Vergisi, Çiftçiyi Topraklandırma Kanunu Türk hükümetinin ekonomiyi düzenleme çabalarının nihai yansımalarıdır. Milli Koruma Kanunu 1940 yılında çıkarılır. Bu kanun savaşın getireceği olumsuz etkiyi önlemekle birlikte sanayi ve maden kurumlarının üretimlerinin hükümet tarafından düzenlenmesini amaçlar. 1942'de Varlık Vergisi uygulamasına geçilir. Varlık Vergisi ile savaş atmosferinden faydalanarak haksız kazanç elde edenleri ve büyük servet sahibi olanları vergiden mesul tutmak amaçlanır. Ancak azınlıklara Müslüman ve Türk mükelleflerden daha fazla vergi borcu çıkartılır. Varlık Vergisi uygulaması, burjuvazinin iktidara cephe almasına yol açar. Türk hükümetinin aldığı bir başka ekonomik tedbir ise Çiftçiyi Topraklandırma Kanunu'dur. Bu kanun ile büyük toprak sahiplerinin toprakları bölünmesi yoluyla küçük çiftçiye destek olmak amaçlanır. Fakat alınan bu karar büyük toprak sahiplerinin iktidara tepki göstermesine neden olur.

“Kırsal alanda da genç kuşakların uzun süreli silâhaltına alınması üretimi düşürmüştü. Oysa başta savunma gereksinimleri olmak üzere, gıda maddelerine olan ihtiyaç eksilmek bir yana daha artmış bulunmaktaydı." (Çavdar,1983: 2063) İfadelerinde de belirtildiği üzere, 1942'de askeri seferberlik nedeniyle erkeklerin büyük bir kısmı silâhaltına alınır. Bu sebeple tarım alanlarında buğday üretimi düşer. Türk hükümeti karne uygulamasına geçer. Bu uygulamaya geçme sebebi tarımsal işgücünü yeniden üretime sevk etmektir. Ekmeğin gramı düşer ve ekmek karneye bağlanır.

\footnotetext{
“Karne sisteminin getirilmesi temeldeki fiyat sorununu çözemedi. Şöyle ki küçük ve orta çiftçiler ancak kendi geçimlerine yetecek bir ekim yaparak piyasaya mal sürmüyorlar, buna karşılık piyasaya mal süren büyük toprak sahipleri ise düşük üretimin getirdiği olanaktan yararlanarak ürünlerini olabildiğince yüksek fiyatla değerlendirebiliyorlardı. Böylece kentlerde ticaret ve sanayi burjuvazisi yanı sıra kırsal alanda da büyük toprak sahiplerinin eline büyük fonlar geçti." (Çavdar,1983 :2063)
}

Netice itibariyle ülkenin aldığı savaş tedbirleri kaotik bir manzara oluşmasına yol açar. Bir yandan karaborsacılıkla zenginleşenler, bir yandan da yeni yeni oluşan kent burjuvazisi, büyük şehirlerdeki ekonomik ve sosyal yaşamda belirleyici rol oynamaya başlar. Taşrada ise, büyük toprak sahipleri daha da zenginleşirler. Bu durum, ülkenin sosyolojik yapısı üzerinde de derin etkilere yol açacaktır. Varsıl kesimler için elverişli sayılabilecek bu durum, enflasyonu arttırdığı için yoksul kesimler açısından hayatı daha da zorlaştırır.

İkinci Dünya savaşının yarattığı kaotik tablo, Türk edebiyatında pek çok esere yansır. “II. Dünya Savaşı'ndan bahseden hikâye ve romanların çoğunda Türk ekonomisinin perişan durumu; savaşla ortaya çıkan kıtlık, yoksulluk, sefalet ve bu durumdan insanların nasıl 
etkilendikleri işlenmiştir." (Çılgın Sınar,2003: 31) Türk toplumunun yaşadığı önemli tarihi süreçleri, geçirdiği değişimleri romanlarına yansıtan Toplumcu gerçekçi yazarlardan biri de Vedat Türkali'dir. “Toplumcu edebiyatı benimsediklerini söyleyen yazarlar var. Bu yazarlar, Marksçı felsefeyi ve dünya görüşünü kabullendiklerini, belli bir sınıf açısından ve bu sınıf yararına eser yaratılarını söylüyorlar." (Hilav,1995: 188) Toplumcu gerçekçi tespiti ile yazarın gerçekçiliğin temsilcisi olduğu öne çıkarılmaktadır. Natüralizmin tek yönlü gerçekçiliği olumsuzluğa yönelirken, romantik anlayış da sanatı duyguların anlatımı olarak görür. Toplumcu gerçekçilikte ise birey ve topluma bütünsel bir bakış söz konusudur.

"Toplumcu edebiyatçı" olduklarını söyleyenler, aslında "gerçekçi" olduklarını söylemek istiyorlar. Gerçekçilik, edebiyatın iç belirlenimlerinden biridir ve çeşitli tarih ve toplum evreleri içinden geçerek belli bir gelişim gösterirler. Natüralizmden, izlenimcilikten köklü olarak ayrıdır. İç ve dış gerçeği (bireyi ve toplumu) derin ilişkileri ve tümlüğü içinde kavrar ve bütünleştirir. Bu etkinlik, bu praksis gerçekleştiği zaman, özlenen savaşkanlık, eylem ve yarar da zaten gerçekleşir." (Hilav,1995: 189) (Vurgu yazara aittir) Kuvveden fiile geçme hali öne çıkmaktadır.

“Tipik olanı kavrayabilen yazar, kendi ideolojisi ne olursa olsun gerçekçi demektir, çünkü değişmenin dinamiğini sağlayabilen tarihi güçleri sezmiş ve anlamıştır. Yaptığı şey hayatın yüzeyine takılıp kalmak yerine, belli bir dönemde o yüzeyin altında yatan tarihi anlamın özüne inmek ve bunu somut kişiler ve olaylarla sergilemektir. Gerçekçiliğin özünü yansıtmak budur Lukacs'a göre ve çağımız kapitalist toplumunda bunu başaranlar eleştirel gerçekçilerdir." (Moran,2011: 56) Toplumcu gerçekçi eserlerde zihinsel tiplerin öne çıktı̆̆ı görülmektedir.

Toplumcu gerçekçi kuram yazara bir misyon yükler. Toplumdan yana toplum yararı yazara sorumluluk yüklerken yazarın ikilik yaşamasına neden olur. Romanda aydın sınıfını temsil eden kesim yaşanan olayları tarihsel ve sosyal bir temele oturtarak sorgular.

“İç içe geçmiş iki sorun, yazın'ın yararı ile yazarın sorumluluğu (görevi), Rus yazınının başlıca belirleyicileri olmuştur denebilir. Toplumcu Gerçekçiliğin, aslında yazınsal değil, aktörel olan bu iki sorunu, bir parti öğretisi biçiminde formüle ettiği söylenebilir. Bu öğretinin yazarlarca gönüllü biçimde kabullenilmesinin nedenlerinin başında, toplumun dönüştürülmesiyle ilgili inanç ve umudun geldiği açıktır." (Oktay,2008: 49) (Vurgu yazara aittir)

Türkali, romanlarında şahıslar aracılığıyla tarihsel zemini yansıtırken aynı zamanda şahısların eleştirel düşünerek ve çıkarımlar yaparak çözümsel bir bakış açısı da sergiledikleri görülebilmektedir: “Bu noktaya gelince eleştirel ve sosyalist gerçekçilik kavramlarıyla karşılaşacağız.[...] Hem varolanı eleştiren hem de olacak olanı dile getirmeye çalışan bu iki tür gerçekçiliğin büyük sanat yaratışlarına kaynaklık ettiği görülüyor." (Hilav,1995:189) 
Türkali'nin Güven adlı iki ciltlik romanı İkinci Dünya Savaşı'na tanıklık eder. Romanın şahıs kadrosu perspektifinden incelenmesi II. Dünya Savaşı'nın topluma etkilerini yansıtması noktasında aydınlatıcı bir yapı teşkil etmektedir.

\section{VEDAT TÜRKALI'NIN GÜVEN ADLI ROMANINDA, ŞAHIS KADROSU PERSPEKTIFIINDEN II. DÜNYA SAVAŞI'NIN TOPLUMA ETKİLERI}

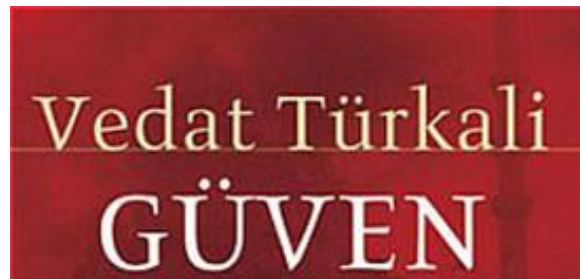

CILT I

Güven romanında şahıs kadrosu perspektifinden İkinci Dünya Savaşı'nın topluma etkilerini incelemek çalışmamızın esasını oluşturur. Güven “İkinci Dünya Savaşı"nı merkez alarak okunabilecek bir romandır. Vedat Türkali, İkinci Dünya Savaşı yıllarında yaşanan siyasal, toplumsal ve ekonomik kaosa toplumcu gerçekçi bir tutumla yaklaşır. Gerçekleşen vurgunları, Almanlarla, İngilizlerle, Amerikalılarla yapılan iş birliklerini, alınan rüşvetleri, varsıllaşma uğruna çevrilen oyunları, işkence ve kıyımları şahıs kadrosu ile yansıtarak tarihsel bir sürece 1şık tutar. Vedat Türkali, bir söyleşisinde yaşadığ 1 dönemin, bir tarihin yok olup gitmesini istemediğini dile getirir. "Toplumcu gerçekçi" bir anlayışla romanlarını oluşturan Türkali, romanlarına dâhil ettiği kişileri de bu bilinçle seçerek roman kahramanlarını ölümsüzleştirir: “Bizler bir çağın, bir toprağın somut yanıyız; bir çağın, bir toprağın somut bilgisini varlığımızda taşırız. Roman kişileri de bu bilgileri varlıklarında taşırlar. Ama bizler ölür gideriz, roman kişileri yaşar"' (Afşar,1974: 7-10)

Romanda zaman, İkinci Dünya Savaşı yıllarıdır. Türkali, bu yılları yansıtırken, savaştan faydalanmak isteyen Türk iş adamları ve yöneticilerini, onların halkın yaşadığı yokluk ve yoksunluğu görmezden gelişini çarpıcı sahnelerle anlatır. Bu işadamları, yöneticiler ve pek çok bürokrat, zenginliklerini arttırmak amacıyla Almanlarla, İngilizlerle ve Amerikalılarla ticaret yapmak peşindedir. Böylece, ülkede savaş varsılları artarken halk daha da yoksullaşır. Yaşanan bu sancılı süreç roman kahramanlarıyla somutlaştırılır. Tarihsel gerçekçilikten beslenerek oluşturulan kitapta Hitler, Mussolini, Roosevelt, Churchill, Stalin gibi dünya liderlerinin izledikleri politikalar da verilir. Avrupa'da, özellikle İtalya ve Almanya'da ırkçı milliyetçilik temelinden ortaya çıkan faşizm ve nasyonal sosyalizm gibi akımlar üzerinde de durulur. Güven romanında dönemin tarihi yaratılan şahıslarla somutlaştırılır. Tarihsel bilincin önemi gerçekçilik yelpazesinde açığa çıkarılır. Tarihsel bilinci ortaya çıkarmak Toplumcu Gerçekçi kuramın önemli bir özelliğidir. 
"Yazarın görevi toplumun belli bir dönemindeki gelişim doğrultusunu belirleyen tarihi güçleri, yani toplumun içyapısını ve dinamiğini kavramaktır. Başka bir deyişle o dönem için tipik olan tarihi durumu anlamak. Yazar eserinde kişiler, olaylar ve durumlarla bu tarihi güçlere somutluk kazandırır." (Moran,2011: 55)

Vedat Türkali, Toplumcu Gerçekçi kuramı romanlarında yansıtmaktadır. Romanlarında Marksist bilincin temsilcileri idealize edilir. Anlatılarında bu nedenle "tip" öne çıkmaktadır: “Öyleyse eserdeki kişilerin, olayların ve durumların tipik olması gerekir ki sosyal gerçekliği yansıtabilsinler. Tipik, ya da temsil edici karakterler hem tarihi güçleri hem de kendine özgü nitelikleri ile yaşayan canlı bir birey olur." (Moran,2011: 55)

Sanat bir yansıtma olarak görülmektedir. Toplumcu gerçekçilikte ise ayna topluma tutulur: “Toplumcu gerçekçiliğe göre sanatın yansıttığ gerçekçilik toplumcu gerçekçiliktir, ama bu gerçekçilik devrimci gelişme içinde görülür ve doğru olarak tarihi somutlukla, işçi sınıfının eğitimi gözetilerek yapılır." (Moran,2011: 53)

Toplumcu gerçekçilik, Marksist ideolojinin geliştiği Sovyet Rusya'dan yayılarak dünya edebiyatını etkilemiştir: "Rusya'da devletin resmi sanat görüşü sayılan toplumcu gerçekçilik 1930'larda ortaya çıkmış ve ana ilkeleri bilindiği gibi, 1934'te toplanan “Sovyet Yazarlar Birliği'nin Birinci Kongresi'nde saptanmıştı." (Moran,2011: 53)

Romanın şahıs kadrosunu, ülkenin kara güçlerini temsil eden bürokrat ve tütün tüccarı Eşref Bey, Hüsnümelek Bey, Galip, Nazif, Mansur Raşit ve işadamı Mithat; burjuva sınıfının tipik kadınları Terzi Nezahat, Mükerrem Hanım ve Zübeyde Hanım; Marksist dünya görüşüne sahip üniversite öğrencileri Turgut ve Halil, devrimci mücadele içerisinde yer alan ve işçi sınıfını temsil eden Rahmi Usta ve aydın kesimi temsil eden Sahir Hoca, oluşturur.

Eşref Bey, üç dönem çeşitli bölgelerden milletvekilliği yapmış varlıklı bir CHP bürokratıdır. Yaşamının çoğunu Ankara'da geçirmektedir. Bürokrat ve tütün tüccarı Eşref Bey, Varlık Vergisi'nden istifade ederek pek çok toprağı yok pahasına satın alan merdud bir tiptir. Ankara'da yaşayan Terzi Nezahat adlı bir metresi vardır. Karısı da dâhil pek çok kişi onun bu ilişkisini bilmektedir, fakat üç maymunu oynamaktadırlar.

“Cumhuriyet Halk Partisi'nin sorumlu yerlerinde görevli olmak, ortaklık ettiği dışalım-dışsatım firmasının bürokraside, hükümet katlarındaki çıkar ilişkilerini açık vermeden sürdürmek bu savaş yıllarında bile gelişen Ankara'yı içi, dışı, çevresi, yöresi ile el altından parselleyip kapatanlar arasındaki yarışmadan kendine, yakınlarına bir şeyler koparmak, gerçekten kolay yürütülür uğraş değildi. Çeşitli katlarda dostları vardı. Bir sürü düşmanı da vardı kuşkusuz. Kolay mı o dengeyi yürütmek? Terzi Nezahat, yalnız bir kadın değil, iş çıkar ortağıydı." (Türkali,2011: 93-94) 
Eşref Bey, romanda Komünizm karşıtı tutumuyla karşımıza çıkar. Sözde Kemalist değerlere bağlı bir bürokrattır: "-Her yerde komünistlere saldırır faşistler Turgut Bey, dedi. Bize ne bundan? Rusların hesabını görüyorlar!" (Türkali,2011: 83) Eşref Bey, bencil bir kişidir. Dünya Savaşı kendi burjuva sınıfını etkilemediği için önemsizdir: "-Boş ver be hocam, dedi. Keyfimize bakalım. Dünya ateş ortasında, biz cennet vatanımızda kavgasız dövüşsüz... Hadi şerefe..." (Türkali, 2011: 103) Bir süre sonra felç geçirerek yatağa bağlı olarak yaşamaya başlar.

Eşref Bey'in karısı, Necla'nın annesi olan Mükerrem Hanım, Alman yanlısı, Komünizm karşıtı

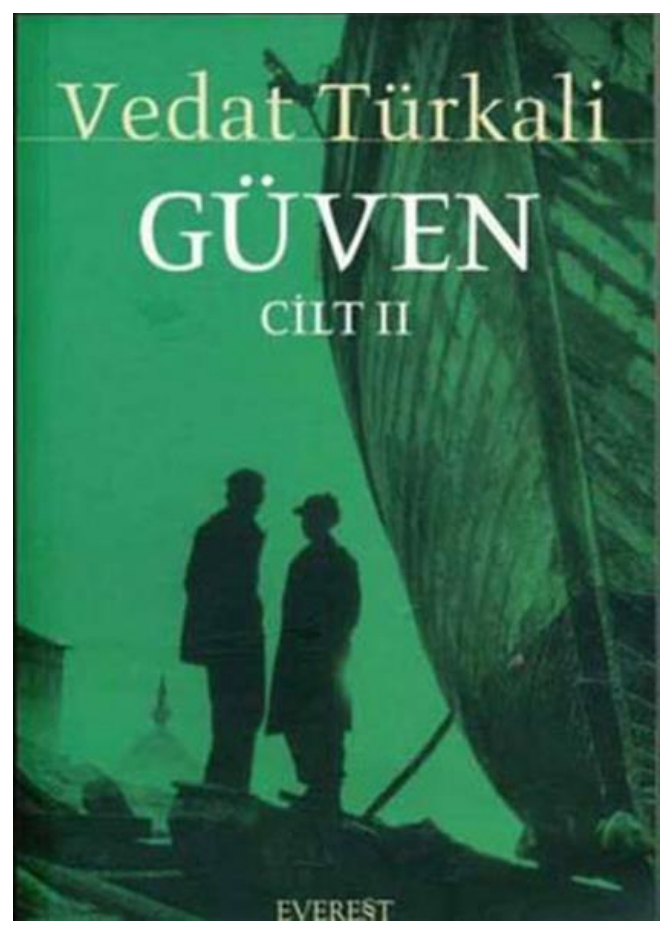
biridir: "-Niye bize saldırsınlar? Bolşevikliği temizliyor adamlar. Almanlar bizim dostumuz kızım. Bolşeviklik kalktı mı yeryüzünden, savaş mavaş da biter kaygılanmayın. "' (Türkali,2011: 12) İyi bir eğitim almamış bir ev kadını olan ve dünya meselelerine gerçek bir ilgi göstermeyen Mükerrem Hanım’ın bu sözleri, kocası Eşref Bey'in düşünce yapısını yansıtır niteliktedir. $\mathrm{O}$, bir bürokrat eşi olduğu için bazı ortamlarda belli konular hakkında yorum yapmak ihtiyacı duyar. Ancak, samimi bir zihinsel değerlendirmeden çok uzak bu sözler, Eşref Bey'in aile yapısı hakkında da dikkate değer ipuçları verir.

Romanın merkez kişisi Turgut'un Refik aracılığı ile tanıdığı Zübeyde Hanım, burjuva sınıfını temsil eden bir tiptir. Bir süre felsefe öğretmenliği yapmıştır. Sayıştay emeklisi Fikri Bey ile evlidir. Kocası Fikri Bey'in Mason olduğu söylenmektedir. Zübeyde Hanım ve eşi, hükümet ile yakın ilişkiler içerisinde olan bir ailedir. Zübeyde Hanım, hükümetin aldığı kararları yerinde bulan ulusçu düşüncelerinde aşırıya kaçan biridir.

“Varlık Vergisi diyorsun! Askeri besleyecek para yoktu bütçede kuzum. Bir iki Ermeni'nin, Yahudi'nin canı yandı diye mi tasalanacağız? İnsanları katur kutur doğruyorlar dünyada. Yazık ki, kapattılar o işi yasa çıkarıp; daha alsalardı keşke! Kaygılanma, en varlıklı gene onlar Türkiye'de!" (Türkali,2009: 22)

Varlık Vergisi ile el konulan malların çoğunun dönemin burjuva sınıfının eline geçmiş olması, romanda da vurgulanan bir tarihi gerçektir. Zübeyde Hanım da bundan yola çıkarak, bu vergi nedeniyle yaşanan pek çok trajik hikâyeyi kolaylıkla görmezden gelir.

Eşref Bey'in kız kardeşinin kocası Hüsnümelek Bey, Alman yanlısı ve ırkçılığa varacak derecede milliyetçi, aynı zamanda da mason bir roman kişisidir. Özellikle masonik ilişkiler 
ağ1 ona yüklü paralar kazandırır. "MAH" la (Milli Emniyet Hizmet Riyaseti)ilişkisi olan merdud bir tiptir:

“Devletimizin başındaki Moskof belası yıkılıyor. Komonistlik temizleniyor. Bize görev düşmez mi? Kırım, Kafkas Cumhuriyetleri, Azerbaycan kurtulmadan bu devlet nasıl rahat soluk alır? Başımızda Rus belası varken Türüke rahat olur mu?

Almanlar bu pisliği temizliyor. Biz olmadan yapamazlar." (Türkali,2011: 104-105)

Romanda sadece MAH kısaltmasıyla adı geçen ve yazarın açılımını vermediği Milli Emniyet Hizmet Riyaseti, dönemde pek çok işkencenin, faili meçhul cinayetin arkasındaki kurum olarak yansıtılmaktadır. Bu kurumla olan ilişkileri, Hüsnümelek Bey hakkında olumsuz bir kanaate yol açar. Hüsnümelek Bey'in, ölürken Galip'e bırakacağı yüklü miktardaki para da hem bu ilişkiler ağı, hem de masonik bağlantıları nedeniyle kara paradır.

Hitler'in nasyonal sosyalizm ideolojisine sözde bağlı olan Galip de, romanın merdud tiplerinden biridir. On yaşındayken babasını yitirir. Babasının devlet adına gizli bir örgütte çalıştığını onun ölümünden sonra öğrenir. Galip, Almanya'da geçirdiği uzun yıllardan sonra Türkiye'ye döner. Öğrencilik yıllarındaki arkadaşlarının pek çoğu İstanbul Üniversitesi'nde çeşitli fakültelerde, yüksekokullarda öğretim görevlisidir. Ankara'da, İstanbul'da bürokratlarla, iş adamlarıyla güçlü ilişkiler kurar. Temel amacı çok zengin olmak olan Galip'in bu uğurda yapmayacağı şey yoktur: "Parti-iş-iktidar çevrelerindeki etkin konumu; askerlerden, Genelkurmay'ın üst katlarından önemli kişilerle ilişkileri, Necla'dan başka kalıtçısı olmayan Eşref Bey'i, oynaması gerekli oyunun en önemli kartı yapıyordu. (Türkali,2011: 276)

Gizli Güvenlikte çalışması için yapılan teklifi kabul eder. Nazif'le birlikte çalışmaya başlar: “Devletin güvencesine kavuşmuştu! Ne olacaktı devletin güvencesinden? Kendi güvencesini kendi sağlayacak güçte olmaktı onun bugüne dek hep kurup düşlediği. Vaz mı geçmişti? Hiçbir şey değişmemişti aslında onun için her şey eskisi gibiydi gene. " (Türkali,2011: 531) Kısa süre içerisinde devlet katında önemli bir mevki elde etmiş olması bile, onu memnun etmeye yetmez.

"Milli Emniyet Hizmeti Riyaseti" içerisinde olan Galip ve Nazif pek çok yasadışı işe karışmaktan çekinmezler. Bir süre sonra Galip, Eşref Bey'in karısı Mükerrem Hanım'ı da dâhil ederek Nazif Bey, Hüsnümelek Bey, Sermet Bey ile Almanlara satmak üzere krom ortaklığı kurarlar. Savaşın seyri Türkiye'nin dış politikasını etkiler:

\footnotetext{
“Almanya'ya krom gönderilmesinin, 21 Nisan 1944 akşamı saat 19'dan itibaren yasaklandığını açıklayan Bakanlar Kurulu bildirisini, bir gün önceki akşam, eve yorgun argın gelip de, radyodan dinlediğinde sinirleri tuz buz oldu birden. Sürpriz değildi ya, bu kadar tepeden iner gibi geleceğini düşünmemiş, günlerdir vagonlarda beklettikleri kromları göndermeden böyle bir karar çıkmasını olası görmemişti niyeyse! Eli kolu bağlı kalıvermişti birden... Peki, ne olacak bu
} 
kromlar? İngiltere'ye, Amerika'ya mı satacağız? Onlara yasak yok. Kara

listelerindeysek bizden krom alır mı bakalım o herifler? (Türkali, 2011: 808-809)

Alınan bu karar Galip'i korkutur. Sözde Alman yanlısı olan Galip, bu durum karşısında büyük bir çelişki sergiler. Söz konusu ticari kazanç olunca gözü başka bir şeyi görmez. Elde kalan kromu Amerikalılara, İngilizlere pazarlama amacı taşır. Bu çelişkisini Eşref Bey'in kızı Necla, şu şekilde eleştirir: “Görüyorsunuz, zor durumda adamlar! Dostlarından destek beklerler pek yerinde olarak. Siz de kromlarınızı satmak için İngilizlerden, Amerikalılardan öneri bekliyorsunuz! Yakışır bir yanı var mı bunun?"(Türkali,2009: 134)

Galip'in zengin olma tutkusu tüm varlığına sinmiştir. Nazif ile ticari ilişkisinden hoşnut değildir:

“Galip'in istediği Fehmi Bey'lerin katında olmaktı, koruma görevlilerinin değil! Düşmanlardan kurtaranlar vardı ülkeyi; geliştirip yükseltenler bir de! İkinciler arasındaydı onun yeri. Nazif Bey engelini aşmadıkça, başında bulunduğu ortaklık, ona bu kapıyı aralasa da, kolay kolay geçemeyecekti o kapıdan. Kafasını hep kurcalaya gelen bu sorun, artık iyice yerleşiyordu içine. Nazif Bey'le İngilizlere attıkları krom kazığı başlarını göğe mi erdirmişti? Kim kime kazık atmıştı; o da belli değildi daha! Getirdiğinden çoğunu götürecekti Nazif Bey. Bu, hep böyle olacaktı." (Türkali,2009: 427)

Daha yüksek mevkiler elde etmek için, kendisine zenginliğin kapısını aralamış bu ortaklığı bozmaktan çekinmeyecektir.

Maddi çıkar kaygısıyla da olsa, evlenmeyi düşündüğü Necla'nın “Milyonlarca insanı doğradılar. Kitapları yakıp bilim adamlarını kovdular. Kamplara yığdılar bir sürü düşünen başı. Yaktılar, yıktılar dünyayı, milyonlarca insana kıydılar." (Türkali,2009: 134) şeklindeki söylemleri ırkçı zihniyetine dokunduğu için Galip'i öfkelendirir. Necla'nın bu söylemlerinden sonra, ondan öç almak için, annesi Mükerrem Hanım'la bir ilişkiye başlar.

Hüsnümelek Bey'in, ölmeden önce kendisine bıraktığı yüklü miktarda para ile Sermet Bey'in hisselerini de satın alarak ortaklığın yüzde altmışına sahip olur. Geri kalan parayla sarraftan altın alır. Alman bankası adına İsviçre'de çalışması teklif edilir. Galip bu teklifi kabul eder ve İsviçre'ye giderek Mükerrem Hanım'ı terk eder. Böylelikle, Almanlara krom satmak için kurulan ortaklık, İngilizlere krom satılmasını sağlamış ve sonrasında Galip, bir kez daha taraf değiştirerek Alman bankasında çalışmaya başlamıştır.

Asıl adı Mahir Çatan olan Nazif, devletin gizli örgütü MAH'ta çalışır. Kendi çıkarları nedeniyle yer altı dünyasının pek çok kirli işine bulaşan merdud bir tiptir. Onun için temel kıymet paradır: “Devlete çalışıyorlardı; onurluydu, yurtseverlikti yaptıkları kuşkusuz. Devletin, ulusun çıkarlarını korurken kendilerini de düşünmeleri gerekiyordu. Sonunda, emekli aylığıyla sürünmek akıl işi değildi. "(Türkali, 2011: 637) 
Nazif, varmak istediği yere devlet desteğini alarak ulaşacağına inanır: "Ancak, yalnızca varsillık yetmez Nadirciğim! Devlet gücü de gerekli. Devletin demir yumruğu ile bizim altın yumruğumuz yan yana gelmedikçe güçlü olamayı!" (Türkali, 2009: 379-80) Devlet'in Almanlarla krom ticareti yasağını getirmesi onu bir anda İngilizlere yakınlaştırır. Bu yakınlaşma, onu “emekli

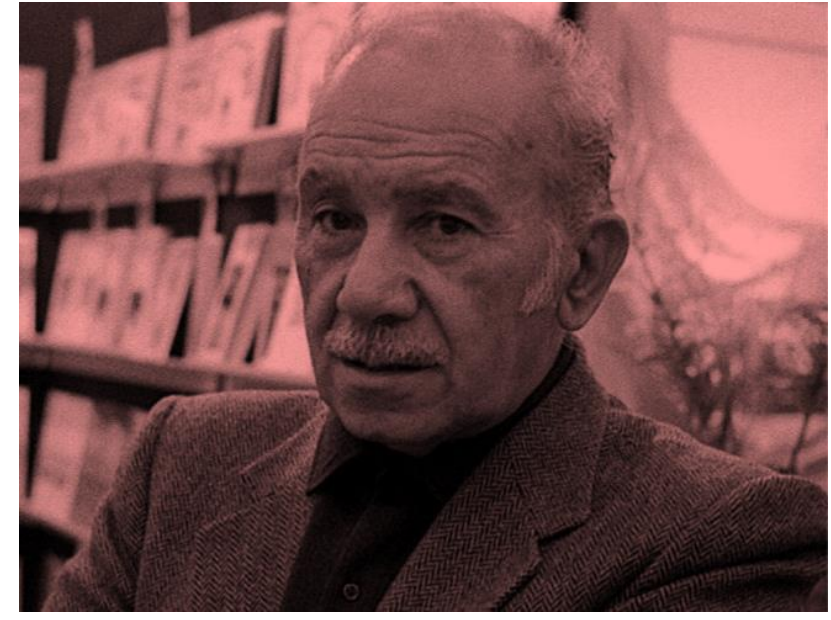

Vedat Türkali aylığıyla sürünmekten” kurtaracaktır. Ancak, Nazif, sözünü ettiği demir yumruğu sadece varsıllaşmak için kullanmaz. O, pek çok Marksist öğrencinin, işçinin ve aydının tutuklanmasında ve işkence görmesinde pay sahibidir. Hatta, hukuk öğrencisi Halil'i öldürmüş ve bu cinayeti ustalıkla örtbas etmiştir. MAH'ın adamı Nazif, 27 Mayıs 1960'ta tutuklanır ve daha sonra serbest bırakılır. Görevden alınır; ancak daha sonra tekrar göreve döner. Ankara' da yaşadığı apartmanın yedinci katından atlayıp intihar ettiği söylenir; ancak ölümünün arkasında gizli güçlerin olduğu ima edilmektedir.

Galip'in arkadaşı Mansur Raşit, İstanbul Üniversitesi'nde felsefe profesörüdür. Alman yanlısı ırkçı bir tutuma sahiptir. Bu düşüncelerini şu şekilde dile getirir: "Her ulus, gerçek ulus bilincine varmışsa kendini üstün görür," demişti. Almanlar nice acı deneylerden sonra akıllılık edip bir kurama dayandırıyorlardı." (Türkali, 2011: 307) Mansur Raşit'in akademik kimliği, yakın arkadaşı olan Galip'in kirli eylemlerinin zihinsel arka planını beslemektedir.

İkinci dünya savaşı yılları hem dünya hem de ülkemiz açısından çeşitli ideolojik kamplaşmaların da görüldüğü yıllardır.

Sovyetler Birliği örgütü Komüntern'in İkinci Dünya Savaşı politikası romanda şahısların perspektifinden yansıtılır. İşçi sınıfını temsil eden Rahmi Usta ve aydın sınıfını temsil eden Sahir Hoca'nın zaman zaman TKP'nin tarihsel sürecine dair yaptıkları sohbetler dikkat çekicidir. Sovyetler Birliği örgütü olan Komüntern, 1935'te yaptığ1 Yedinci Kongre'de komünist partileri savaşa, faşizme karşı barış ve demokrasi yanlısı güçlerle işbirliği içerisine girmeleri için görevlendirir. Sınıf sınıfa karşı mücadelenin yerini sınıflar arası kavga alır. Faşizme karşı demokratik savaş kararı alınır. Komünist Partileri'nin desteği ile Fransa'da, İspanya'da Halk Cephesi hükümetleri kurulur. Komintern, dünya ülkelerini; savaş yanlısı ve savaşa karşı olarak ikiye ayırır. Türkiye'yi ise savaşta çıkarı olmayan ülke olarak kabul eder. Türkiye Komünist Partisi'ne düşen görev barış çizgisinde olan Kemalistleri demokrasi yoluna çekmek, faşist Almanya ile ilişkilerinin gelişmesine engel olmak ve Sovyet dostu, emekçi yanlısı bir politika izlemektir. Ancak TKP, Komintern'in bu kararını 
gerçekleştiremeyince "separat" olarak da adlandırılan 1937'de verilen desantralizasyon kararıyla TKP’nin örgütsel olarak gizli çalışması yasaklanır. Cumhuriyet Halk Partisi'nde demokrasi ve anti-faşist barış için Kemalistlerle birlikte çalışmalarına karar verilir. Ancak örgüt bu kararı da gerçekleştiremez. TKP'de önemli bir konuma sahip olan Reşat Fuat, askerden kaçar. İstanbul'da gizlenir. TKP 1938'de Harp Okulu ve Donanma olaylarından sonra Reşat Fuat'la yeniden harekete geçer. Rahmi Usta, Halil, Turgut ve bir grup arkadaşlarının örgüt için çalışmak istediklerini Reşat Fuat'a söyler. Reşat Fuat, gençlerin çalışmalarını onaylar. TKP ile bir bağ kurup çalışmak amacıyla uzun süre bekleyen Halil dışındakiler Parti ile çalışmaya başlar.

Romanda, İkinci Dünya Savaşı yılları sadece işbirlikçi, karaborsacı ya da bireysel çıkar peşinde koşan olumsuz kişiler üzerinden yansıtılmaz. Söz konusu süreçte toplumun farklı katmanlarında farklı kaygılar taşıyan, farklı yaşam biçimlerine sahip kişiler de vardır. Çoğunluğu olumlu özelliklere sahip bu kişilerden ilki, Sahir Hoca tipidir. Bu durum olumlu kahramanlar öğretisini akıllara getirmektedir. Lukacs, olumlu kahramanlar öğretisine eleştirel yaklaşır. “Lukacs'ın, toplumcu gerçekçiliğin Sovyetler'de geliştirilmiş şekline ve uygulanışına katılmadığı bir nokta da "olumlu kahramanlar" öğretisi idi; yani okurun saygı duyacağı, imreneceği ve taklit etmek isteyeceği kahramanlar sunmak." (Moran,2011: 60) Merdud tipin karşıtını oluşturur. Fakat olumlu kahramanların eyleme geçemeyen edilgin bir tarafı da vardır. Sahir Hoca, okuyan ve eleştirel bir tutum sergileme noktasında iyi olmasına karşın eyleme geçme gücünden yoksun bir tiptir. Bu bağlamda Rus edebiyatının yaygın tiplerini hatırlatır:

“O çağda Rus edebiyatında ağır basan bir tip vardı: zekâsı parlak, duyarlı̆̆ı ince, ama karamsar, bir işe yaramaz, topluma karşı olumsuz adam. Bazen iyi niyetli ve ümitli olsa da eyleme geçemeyen, sonunda hep yenilgiye uğrayan adam. Bu tipe gereksiz adam deniyordu, çünkü ilk defa Puşkin, kahramanı Eugene Onegin için bu deyimi kullanmıştı. Lermantov'un Zamanımızın Bir Kahramanı'ndaki (1840) Peçorin, Turgenyev'in Rudin'i bu tipin örnekleridir." (Moran , 2011: 60) Sahir Hoca, zeki ve duyarlı, fakat eylemeye geçemeyen son tahlilde korkudan azade olmayan biridir.

Her şeye kuşkuyla bakan Sahir Hoca, romanda zihinsel bir tip olarak karşımıza çıkar. Sahir Hoca, küçük burjuva bir aydın olarak romanda yer alır. Dört yıl kadar Fransa'da Sorbon'da Felsefe eğitimi alır. Bu dönemde Fransız Komünist Partisi'ne girip çıar. Kendisini şu şekilde tanımlar: “Ben sosyalistim. Lenin Komünizmi'ne bağlıyım.” (Türkali, 2011: 471) Yaşanan zorlu süreçte aydınların sorumluluklarını yerine getirmemelerini eleştirir: "-Halk acınacak koşullar içinde. Savaş var deyip uyutuyorlar milleti. Hele şu son bir yıldır soygun gırla. Halk perişan. Ama örgütsüz. Hırsızlarla ortakların eline kalmış ülke. Aydınlar dersen, 
herkes kendi dümeninde. Zaten aydın denecek kaç kişi var ya..."(Türkali,2011: 482) Sahir Hoca, başta kendisi olmak üzere entelijansiyayı bireysel çıkarlarını önemsediği için suçlamaktadır. Bu tespit Zamanımızın Bir Kahramanı olan Peçorin'in eleştirisini düşündürmektedir:

“Lermantov'un bozulmayı içinde en önce duyan, yabancılığının farkına varan bu garip kişisi şöyle der: "Kendimden nefret ediyorum, başkalarından da nefret edişim de bundan ileri gelmiyor mu zaten? Varlığının anlamını ve bütünlüğünü yitiren Peçorin'in sözlerinde bir suçlama olduğu kesin. Kuşku yok: Örtük tavır bu; yine de tüm anlatı boyunca duyumsatıyor kendini." (Oktay, 2008: 50)

Toplumcu gerçekçi romanlarda kurtarıcıya duyulan gereksinim Ahmet Oktay'ın kurban, suçlu, kurtarıcı.(Oktay, 2008: 49) imgelerini düşündürmektedir.

Sahir Hoca, devrimcilerin Sovyet Rusya'nın komünist lideri Stalin'i sorgulamadan âdeta tapar derecede benimsemelerini doğru bulmaz. Her firsatta bu durumun yanlış olduğunu dile getirir. Stalin'e eleştirel yaklaşanları hain olarak niteleyenlere kızar. Olayları tarihsel ve sosyal bir zemine oturtarak sorgulamasına ve bu tutumunu doğru bulmasına rağmen, bu düşünceleri eyleme dökmez. Türkali, romanlarının çoğunda, benzer nitelikteki aydınlara yer vererek aydın kesim eleştirisini gerçekleştirir. Onun romanlarında, özellikle sol ideolojiye sahip aydınlar, devrimci mücadele sonrasında iş, evlilik, anne babalık gibi roller bürünmüş olmanin etkisi ve bireysel tutuklukla bu mücadeleden kalben olmasa da somut anlamda uzaklaşmış kişilerdir. Hatta onlar bu durumun bilincinde olan ve bunun yükünü taşıyan, bu nedenle de huzursuz kişilerdir.

Rahmi Usta, Moskova'da yetişmiş eski bir Parti'lidir. Tornacı olan Rahmi Usta, devrimci mücadelede yer alır. Siyasi görüşlerinden dolayı hapse girmiş, işkencelere maruz kalmıştır. Üniversite öğrencisi Halil ve bir grup arkadaşları ile görüşmeyi kabul ettiği sırada dünyanın ve ülkenin içinde bulunduğu savaş koşullarını şu şekilde değerlendirir: "Nazilere karşı dünya savaş veriyor, bizimkiler Nazilerle uyum içinde. Halk soyuluyor. Yalnız işçi sınıfı diye almamak gerekir. Dizginleri elinde tutanların koruduğu bir avuç vurguncu dışında ezilip soyulmayan halk yok bugün Türkiye'de." (Türkali, 2011: 463) Rahmi usta, bilinçli bir işçidir. Ülke ve dünya gerçeklerini kendi bakış açısıyla değerlendirir, ancak onun en ön plandaki özelliği dürüst, namuslu bir kişi oluşudur.

İstanbul Üniversitesi'nde Türk Dili ve Edebiyatı bölümünde okuyan Turgut, Manisalı yoksul bir aileden gelmektedir. Turgut, üç yıla yakın bir süre Parti'yi arar. Rahmi Usta vasıtasıyla Parti'ye kabul edilir. Bir süre sonra Parti tarafından görevlendirilir. Sürgünde bulunan Halim Akkanat'a bir pusula götürmek üzere Kirşehir'e gider. Daha sonra komünizm propagandası ve Parti ile işbirliği nedeniyle eş zamanlı tutuklamalar yapılır. 
Turgut da gözaltına alınır. Birinci Şube Emniyet Şefi tarafından günlerce falakalara yatırılır. A ğır işkencelere maruz kalır. Ancak çözülmez.

Halil, İstanbul Üniversitesi Hukuk Fakültesi üçüncü sınıf öğrencisidir. Halil, Turgut ve bir grup arkadaşı ile Parti'yi aramaktadır. Örgütlü bir şekilde devrimci mücadelede yer almak temel amacıdır. Ankara'da tutuklandığı dönemde tanıştığı Mazlum'a yıllar sonra rastlaması hayatının seyrini değiştirir. Mazlum, Parti'nin Merkez Komitesi'ne bağlıdır. Halil, örgüte bağlanmak istediğini Mazlum'a söyler; ancak Mazlum'un Parti'ye dair tutumu Halil'in kafasını karıştırır:"-Sovyetler birliği ölüm kalım savaşı veriyor. Tarihin ilk işçi-köylü devletini yıkacaklar diye korkuyoruz. Bülten çıkaracağız! Kaç kişi okuyacak? Biz söyleyip biz dinleyeceğiz gene. Bir de polis...Öyle mi?.."(Türkali,2011: 290) Halil, Mazlum'un bu söylemlerinden sonra Parti ile çalışmaz.Halil, Mazlum aracılığı ile Sovyet Büyükelçiliği'nde görevli olan Mihail ile gizli bir şekilde çalışmaya başlar.Halil, arandığı için bir süre Sovyet Elçiliği'nde gizlenir. Daha sonra sevgilisi Seher ile Sitare'nin bulduğu bir evde saklanır. Ancak bir süre sonra MAH tarafından yakalanır. Uğradığı ağır işkenceler sonunda ölür. Aynı ideolojik tutuma sahip olmalarına rağmen, Turgut ve Rahmi ustadan farklı bir yol seçen Halil, ülkede o yıllardaki ideolojik mücadelelerin varlığını ve sol kesimdeki önemli fikir ayrılıklarını ortaya seren bir roman kişisidir.

İşadamı Mithat'ın metresi şarkıcı Sitare, katıldıkları bir düğün töreninde acı bir çığlık misali haykırır. Dügüüde Sitare'den şarkı söylemesi istenir; ancak reddeder. Bunun üzerine Mithat, söylemesi için ısrar eder. Sitare, söylememek için direnir. Mithat'a ve zevk ü safa içerisinde olan burjuva sınıfına halkın yokluk ve sefalet içerisinde olduğunu haykırır. Bu nedenle öldürülür. Aslında onun adil olmayan yaşam şartlarına bu başkaldırışı halkın sefaletini gözler önüne serer. Gözü karalığı canından olmasına neden olur.

“Çek elini ulan hırsız pezevenk! Söylemeyeceğim dedim! Mithat'ın,yumruğa benzer tokadı da aynı anda indi kızın yüzüne.Kötü vurmuştu.Eli dudaklarındaydı kızın.Kan mı vardı ağzında?Kaskatı kesilmişti Turgut.Atılacak oldu.Niye,nasıl atılacaktı?..da ne yapacaktı?...Sersemliği bırak ulan! Ne şarkısı ulan! Orospu çocukları! Bok yiyesiceler! Şarkınıza da sıçayım sizin, ağzınıza da! "aç millet, soyguncu orospu çocukları pezevenk hırsızlar" sözcükleriyle karman çorman bir çığlık içinde bas bas bağırıyordu ki, kordonu çekip sesi kapattı birisi" (Türkali,2009: 202)

Sınıf bilincine sahip olmasa da, halkın yaşadığı sıkıntının, yokluğun farkındadır. Trajik yaşam öyküsü, karşılık bulamamış aşkı, metres konumuna düşmüş olması gibi etkenler onun hem çöküşünü hızlandırır, hem de kaybedecek şeyi olmaması ile açık sözlülüğünü besler. Öfkeli bir anında görmekten geri kalmadığı gerçekleri çarpıcı biçimde ifade eder. 


\section{SONUÇ}

Sanat anlayışını Toplumcu Gerçekçi bir temele oturtan Vedat Türkali, sanatın toplumsal bir işlevi olduğu inancındadır. Yazar, İkinci Dünya Savaşı yıllarında yaşanan siyasal, toplumsal ve ekonomik kaosa gerçekçi bir tutumla yaklaşmıştır. İkinci Dünya Savaşı'nı ve Komüntern-TKP ilişkisini, alınan kararları roman kişileri aracılığıyla eleştirel bir tutumla sergilemiştir. Türkali, eleştirel yöntemden kopmaksızın toplumun gelişmesinde tarihle olan bağın önemini şahıs kadrosu ile yansıtma sorumluluğunu üstlenmiştir.

Şahıs kadrosu perspektifinden İkinci Dünya Savaşı'nda gerçekleşen vurgunların, alınan rüşvetlerin, varsıllaşma uğruna çevrilen oyunların, Almanlarla, İngilizlerle, Amerikalılarla yapılan işbirliklerin, o dönemde yaşanan ideolojik mücadelenin ve belli kesimlere yönelik tutuklama, işkence gibi güvenlik gerekçeli uygulamaların topluma etkileri yansıtılarak tarihsel bir sürece 1şık tutulmuştur. Türk ekonomisini düzenlemek için üretilen Milli Koruma Kanunu, Varlık Vergisi, Toprak Mahsulleri Vergisi, Çiftçiyi Topraklandırma Kanunu gibi kanunların bu süreçte savaşın olumsuz sonuçlarını ve kaotik manzarasını önleyemediği yansıtılmıştır.

Yazar, özellikle roman kişilerinden yola çıkarak, onların bireysel gerçekliğini derinlemesine incelerken, bir yandan da onları toplumsal panoramanın parçaları olarak sunar. Kişiler aracılığıyla çizilen toplumsal panorama, belli tarihi süreçleri gerçekçi ya da farklı açılardan görebilmek açısından önemli bir katkı sağlar. Yazar, romanlarında tarihe yaklaşım biçiminin nasıl olması gerektiği ya da aydın-halk ilişkisinin tarihî seyri gibi meseleler üzerinde de durarak, tarihî olanla güncel olan ya da tarih-birey ilişkisi hakkında bilinçli bir tutum sergiler. Bu tutum, onun tarihe ve topluma yaklaşım biçimini öne çıkaran unsurlardandır.

Türkali "Güven"de yer verdiği şahıslara tarafsız bir tutum sergileme çabası içindedir. Ancak sanatçının ideolojik tavrı romanda varlığını hissettirir. Örgütlenerek mücadele etmenin ve bu mücadelenin bilinçli ve güçlü bir aydın kesimle geçekleştirileceğine olan inancının izlerini görmekteyiz. Bu inancının etkisiyle devrimci mücadele içinde yer alanlara daha olumlu bir yaklaşım sergilediği de göz ardı edilemez.

Yazar, işbirlikçi, fırsatçı, çıkarcı kesimlere yönelik eleştirisini olumsuz nitelikte kişiler üzerinden yansıtır. Bununla birlikte, onun hemen her romanında eleştirmekten geri durmadığı bir kesim de halktan kopuk, bireysel dünyasından çıkamayan, kararsızlığın huzursuzluğunu yaşayan aydınlardır. Sınıf bilincine sahip işçiler, üniversite öğrencileri yazarın kendi ideolojik yaklaşımını sergilemesine meydan verecek biçimde çeşitli fikir ayrılıkları içinde çizilir. 


\section{KAYNAKÇA}

Çavdar Tevfik (1983). "Demokrat Parti",Cumhuriyet Dönemi Türkiye Ansiklopedisi C: VIII, İstanbul: İletişim Yayınları.

Çılgın Sınar, Alev (2003). Türk Roman ve Hikâyesinde İkinci Dünya Savaşı, İstanbul: Dergâh Yayınları.

Hilav, Selahattin (1995). Edebiyat Yazıları, İstanbul: Yapı Kredi Yayınları

Moran, Berna (2011). "Edebiyat Kuramları ve Eleştiri", İstanbul: İletişim Yayınları.

Oktay, Ahmet (2008). “Toplumcu Gerçekçiliğin Kaynakları Sosyalist Realizm Üstüne Eleştirel Bir Çalışma, İstanbul: İthaki Yayınları.

Timuçin, Afşar (1974). “Romanda Romancinın Yeri”, Yeni Ufuklar, nr. 254.

Türkali, Vedat (2009). Güven II, İstanbul: Everest Yayınları.

Türkali, Vedat (2011). Güven I, İstanbul: Everest Yayınları. 